\title{
総説 4
}

\section{手術支援画像：臨床的立場から}

\section{〜診断と治療の融合に基づくコンピュータ外科の現状〜}

\section{Operating Assisted Imaging from Surgeon's Point of View Present State of Computer Aided Surgery Based on Fusion of Diagnosis and Treatment}

\author{
伊関 洋，村垣善浩，杉浦 円，南部恭二郎，中村亮一，高倉公朋 \\ 東京女子医科大学大学院先端生命医科学研究所先端工学外科学分野
}

\section{Hiroshi Iseki, Yoshihiro Muragaki, Madoka Sugiura, Kyojiro Nambu, Ryouichi Nakamura, Kintomo Takakura \\ Institute of advanced Bio-medical Engineering \& Science, Graduate School of Medicine, Tokyo Women's Medical University}

\begin{abstract}
A medical system for 21 st century should enable surgeons to reliably provide medical services of high and ubiquitous quality. This will be achieved by sharing all the information with team members, objective and appropriate decision making and work sharing by the team, and making good use of "visualized" treatment process based on the information management, simulation, and database by taking advantage of IT . This means that to achieve the goal while optimizing the strategy toward the goal (a road map) by monitoring real-timely the pre- and intraoperative surgical planning and the operating condition of surgical devices under the control of the surgical strategy system.
\end{abstract}

Key words

Medical traceability, Robotic surgery, Target controlled management, Intelligent operating theater.

\section{1.はじめに}

コンピュータ外科は，1980 年代後半より，コンピュー タ統合による診断・手術プランニングが先行し, 手術ナビ グーションへと発展してきた. 更に, 外科医の新しい手で ある intelligent manipulator としてのロボット手術が始まり 1) ,2)，外科医の新しい眼である術中画像診断が当たり前の 時代となった．診断・プランニング・ナビゲーションは既 に, 術中にリアルタイムになされることが要求されている.

東京女子医科大学大学院先端生命医科学研究所

干162-8666 東京都新宿区河田町 8-1
外科医の新しい脳は, 術中の状況および行為を一元管理し, 客観的にモニタリング・アセスメントすることにより治療 を確実に予測したとおりの結果まで安全に誘導する次世 代のシステムである ${ }^{3), 4)}$. また, 処置・手術にトラブルが 発生した時には，程度の差こそあれ,専門医でも研修医で もその対処にリアルタイムでの決断が迫られる.

コンピュータ支援技術で, 現状の事態を解りやすく呈示し, その解決法を解りやすく示すことで, 混乱を防止し悪循環 の輪を断ち切ることが可能となる.これを実現するリアル タイムデシジョンメーキングサポート(real time decision making support)のコア技術の一つが三次元医用画像である. 三次元医用画像とは，医療情報の可視化に他ならない．以 前は，医療スタッフは各自のイメージ空間で，経験により 
多数の二次元画像から三次元画像に再構成することで情 報を直感的に把握していた. 現在は, 誰が見てもデジタル 化された医療三次元画像を客観的に評価し, 情報を共有す ることで診断・治療をチームで行なうという時代にマッチ した情報処理が身近になったのである. そのためには術中 にCT やオープン MRI のボリューム撮像を行ない術中の イメージングを三次元画像化し, 常に up-date した画像デ 一夕を基に real time up-date navigation を行い, 臓器や手術 対象の変形に伴う移動・変化の問題を解決するシステムが 必須である. 術者は常時, 今操作している位置が本当に計 画した通りの箇所であるかどうか, 計画した通りに操作が 進行しているかどうか, 手術操作による臟器の変形や移動 などの術中の確認作業を, 経験や勘に頼らず客観的に評価 し, 手術器具の操作状況のログを時系列で収集・記録(イ ベントレコーディング)するだけではなく計画どおりに行 なわれているかを照合し, 解析する必要がある(メディカ ルトレーサビリティーmedical traceability:治療・看護履歴 管理). またどこにいても, いつでも一定品質の医療を提 供するのが，これからの医療システムである。これらを実 現するためには, 一定のガイドラインに従って,「可視化」 された情報をチームで共有し, チームで医療を行ない, さ らに予防・診断・治療を一貫させる治療戦略システムの構 築が必須である。

\section{2. 診断即治療の時代に突入}

術中診断技術の発達により, 診断から治療までの時間差 はほぼ 0 となりつつある. すなわち, 診断即治療のリアル タイム性を追求する診断と治療の融合である.このゴール は, 術中にリアルタイムの治療決断をサポートするシステ ムのコアである. 決断のための情報がリアルタイムに更新 されるシステムが整備されると同時に, 治療行為の結果は 即座に評価され, 時事刻々の変化に対応した, 次の最適な option が提示されることになる.これらを実現し支える技 術として, 術中に病巣と正常組織の境界を峻別するセンサ 一と, 治療を加えるマニピュレーションが一体化したシス テムが要求される.また, 術中の治療は取得した術中情報 を基に, 正確に CAD(Computer aided design) でプランニン グしたとおりに治療装置をコントロールする必要がある.

\section{3. 手術の工程解析 · 三次元 CAD シミュレータに よる手術手技の検証と治療器具の干渉の回避と 運用のシミュレーション}

情報技術, 可視化, マニピュレーションが, 今後の外科 治療の目指す方向である. 更に, 医療(特に手術・治療)の 安全を如何に確保するかが重要なトレンドとなってきて いる. 手術を一つの生産ラインと考えると, 部分最適化に
よる術式や手術器具の改良は別な部位での手術操作のボ トルネックを生み出すことになる. 全体を考えての術式や 器具の最適化が絶対必要である. まず術前に, 対象疾患部 位の三次元画像情報を基に，手術操作に必要な最適な access root や最低限必要な手術空閒の確保, 目的を遂行寸 るために必要な器具の形状や機能の検討が重要である.ま た，同時に三次元 CAD を使い，手術工程に従った三次元 位置情報を基にした手術操作・器具のシミュレーションを シナリオどおりに展開・検討する必要がある. 術者は, 手 術シナリオに沿って術野の状況に応じた問題点・ボトルネ ックを洗い出しを行なう。まず, 物理的な制約の中での最 適な access 空間での器具の操作の問題点, 対象臓器(target) にアプローチし温存しなければいけない機能や領域を確 保するための問題点, 手術操作や対象臟器のマニピュレー ションの問題点を明らかにする必要がある.一連のシミュ レーション動作は, 時系列ロードマップとして表示される. オープン MRI のボリューム撮像で, 術中の状況を三次元 画像化し，常に up-date した画像データを基に real time up-date navigation を行ない, 臓器や手術対象の変形に伴う 移動・変化の問題を解決する. 術者は常時, 今操作してい る位置が本当に計画した通りの箇所であるかどうか, 計画 したロードマップ通りに操作が進行しているかどうかを 確認・照合し, 手術操作による臓器の変形や移動などの術 中の確認作業を経験や勘に頼らず, 客観的に評価しその差 分を最小にすることで計画通りに手術を遂行する.同時に， 手術器具の操作状況のログを時系列で収集・記録(イベン トレコーディング)するだけではなく計画どおりに行なわ れているかを照合し, 解析するデータベースに基づいた統 合処理システムの構築である ${ }^{5)}$. また, 手術の安全を確保 し, 常に検証し改善していくためには, 新しい手術システ 厶や治療器具の開発, 手術方法の改良, 精密な画像診断に 基づく手術計画, 合理的かつ系統的なトレーニングが, 重 要である. 特に, 新しい器具の開発や開発された器具によ る新しい手術手技の構築のためには, 手術(治療)三次元シ ミュレータが必須である. 特に, 治療環境因子, 臓器(target) の 3D 座標も含めて, 立体的な治療 access の最適化に威力 を発揮することになる. 新たに開発されるマニピュレータ は, 従来の器具のように直線でのアプローチに限局されな いため, スネークアームに代表され自在な屈曲が可能なマ ニピュレータと臓器および他の器具との立体的な干渉問 題が発生する.内視鏡手術の発達に伴い, 従来の直視下で 手術器具と対象臟器を術者がコントロールするのではな く, アクセスポートが限られており, 複雑な動作をする器 具と対象臓器および他の器具を無理なく操作することを 手術スタッフが要求している. そのためには, 術前に対象 臓器に対するアクセスおよび必要な器具だけでは無く, ど 


\section{Advantage of intraoperative MRI}

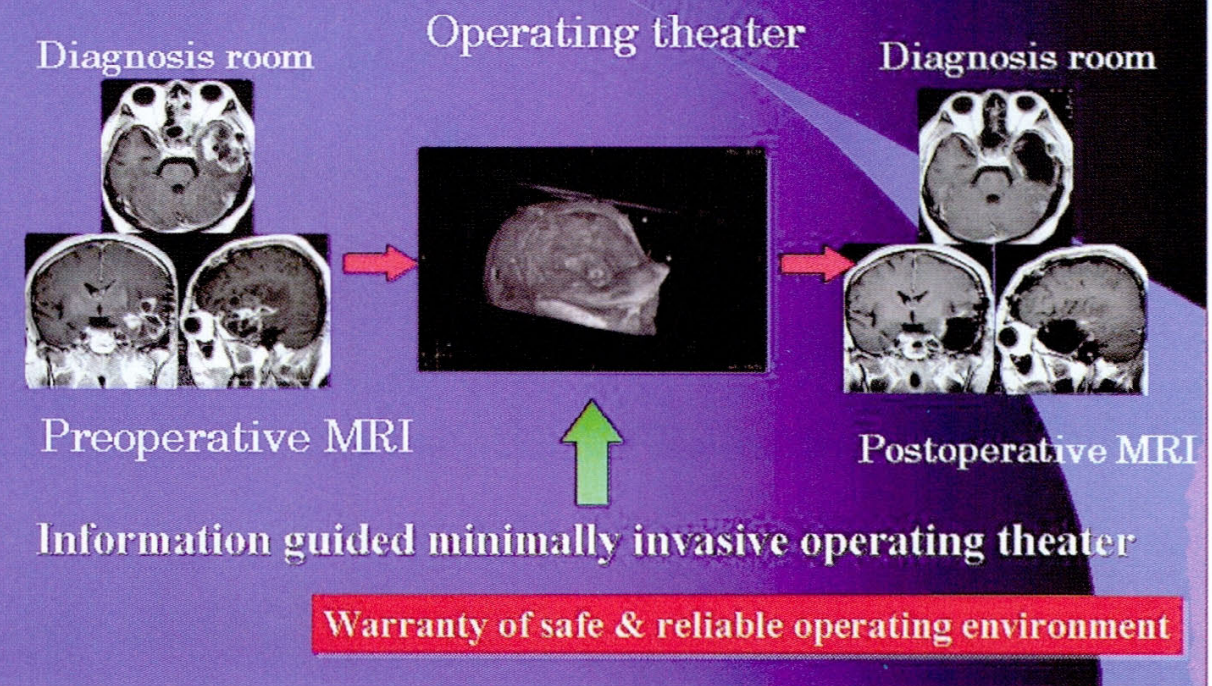

Fig. 1 術中画像の有用性

のような操作をするかなどの手術工程解析に基づく術前 のシミュレーションが必須である。このシミュレータは, 術前には予定する治療法の最適化システムとなり, 事前に 治療のオプションして選択した事による治療結果を術者 だけではなく, 治療スタッフや患者・家族への治療法と結 果の明確に示すことにもなる. 術中には, 状況に応じてリ アルタイムにシミュレーションし, その結果に基づいて治 療の最適化をはかることも可能となる. 最終的には, 転州 シミュレータ (5 年後)に進展することとなる. 治療行為と その治療結果のデータベースの構築と蓄積により, そのシ ミュレーション精度は, 飛躍的に高まることとなる. 結果 として, 患者の状態・質 $\cdot A D L を 2$ 年後, 3 年後, 5 年後 で, どの程度に保ち, それを実現するための最適な治療法 を提示することとなる. また, 患者の希望, 環境に応じて 治療法等は選択されるべきであり, 例えば, 2 年間は普通 の生活ができれば, 残りは死んでも良いとか, 3 年間は, この水準を維持して欲しいとか, 半年間でも良いから, 望 みのことができれば良いとか. 患者の希望・状況・環境に 応じてシミュレータで転帰までのロードマップを作製し て, そのプロセスを管理することになる. 当然, 予定され た転帰まで, 患者の状態を維持し保証するシステムである. すなわち, target control management system(TCM)である.

$\mathrm{TCM}$ を加味した手術三次元 $\mathrm{CAD}$ シミュレータに要求 される仕様としては, (1)十ビゲーションシステムへの手術 デザイン入力, (2)手術デザインに基づくマニピュレータの 動作シミュレーション, (3)手術ザインに基づくマニピュレ 一夕の位置, 姿勢, 動作の制御の最適化, (4)手術デザイン
と実際の位置, 姿勢, 動作との差異の術者へのフィードバ ックおよびリアルタイムの臟器変化に対応するリアルタ イムフィードバックによる最適化が必須である.

\section{4. 医療情報の可視化に基づく手術支援機能を究 めるデザイン (提示技術) と Image driven development}

臨床に密接に結び付いた条件での医用機器開発が必要 である. 特に欧米に比べて遅れている, 医療界の産学協同 研究を推進し, 効率的にかつリアルタイムに医療ニーズを 捉え，それを実現する技術開発を行なら施設・システムの 整備がこれからの国際競争力を考えると最重要な事項で ある。開発段階から, 医者(使用者) と工学者の作製する医 用機器のインターフェースが重要であるにも関わらず, 本 邦では医療側と工学側が別々のスタンスで, ニーズとシー ズがお互いに理解されないまま推進されている. その結果 として出来上がった物は, 臨床の場で必ずしも生かされて いないのが現状である. 使い勝手や必要な機能がサポート されていず, 逆に過剩な機能があったり明らかに不要な機 能や医療現場では使いこなせない操作性が付加されてい ることが多い。医療機器・システムや医療情報の可視化・ 提示装置は, 機能を究めるデザインと Image driven development の発想で開発しなければならない.

工業デザイナーとして著名な柳宗理のデザイン「用と 美」は，使い勝手の良さ，すぐれた近代的技術の使用，す ぐれた材料, 大量生産にあった（プラットホームとして優 れている）デザイン，経済性にある。 


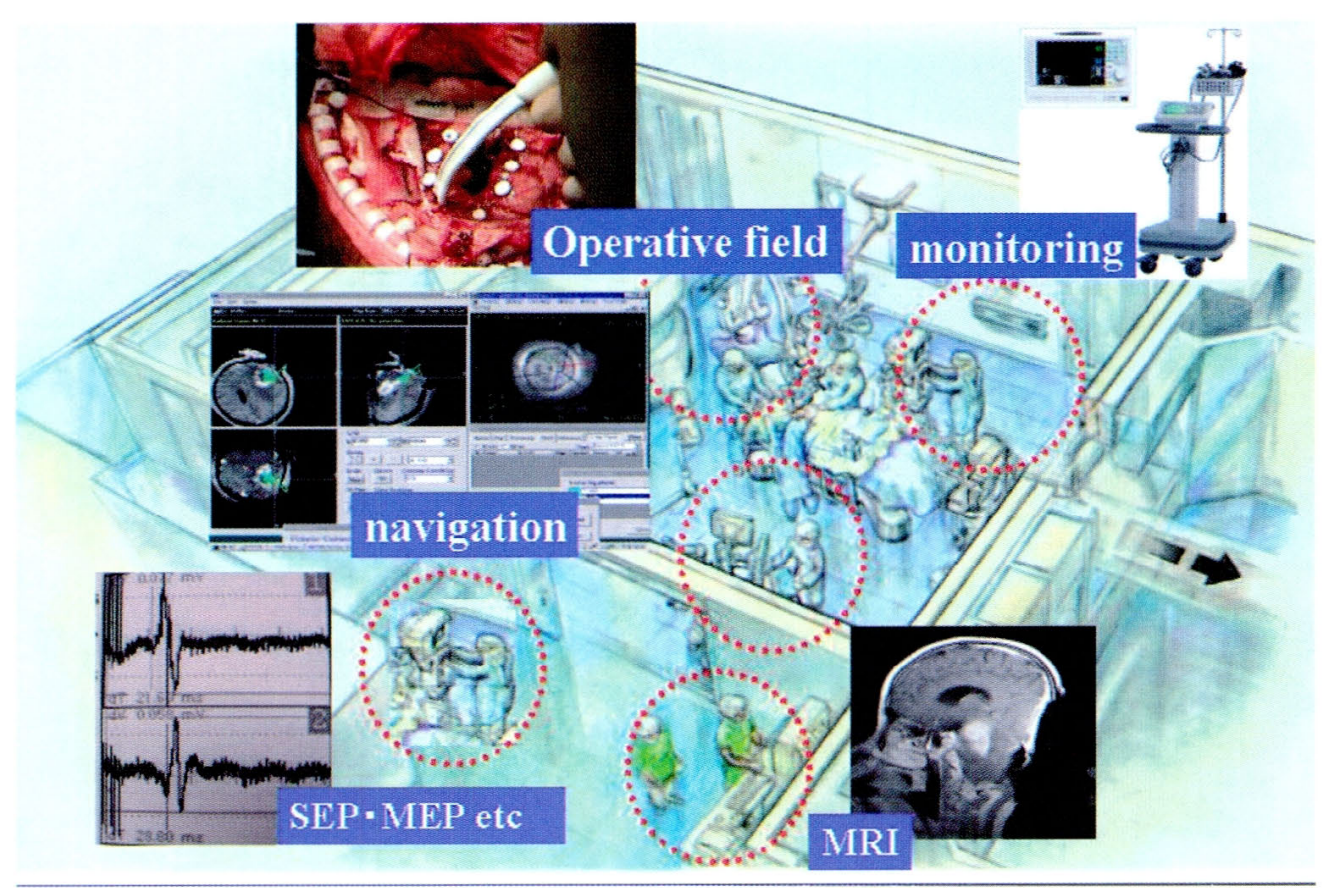

Fig. 2 インテリジェント手術室での情報の可視化

すなわち，

1. 機能(使い勝手)がすぐれていること。

2. 守ぐれた近代的技術(テクノロジー)が用いられてい ること.

3. すぐれた材料が適宜に利用されていること.

4. 大量生産(無駄を排し研ぎ澄まされた形状でユニバー サル使用に堪えるプラットホーム) にあったデザイン がされていること。

5. 経済性つまり無駄を省いた合理的なデザインがされ ていること.
である。また，様々な条件を考虑しつつ，技術者(異分野 の研究者) との協同作業の中で技術面から検討を重祇, 各 段階で可能な限り試行錯誤, 修正しながらデリ゙インを決定 していく手法に他ならない。すなわち, 「器具・装置やシ ステム，支援情報機能のあるべき姿，“イメージ”を思い 描き，その価值をわかりやすく提案し具体化する」ことで ある。さらに，開発する医療機器・システム，支援情報機

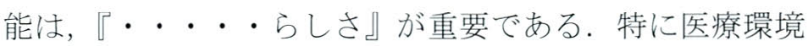
に調和すること, 使用者にとっての信頼感・清潔感が不可 欠である。また，医療スタッフにとって使いやすいものを

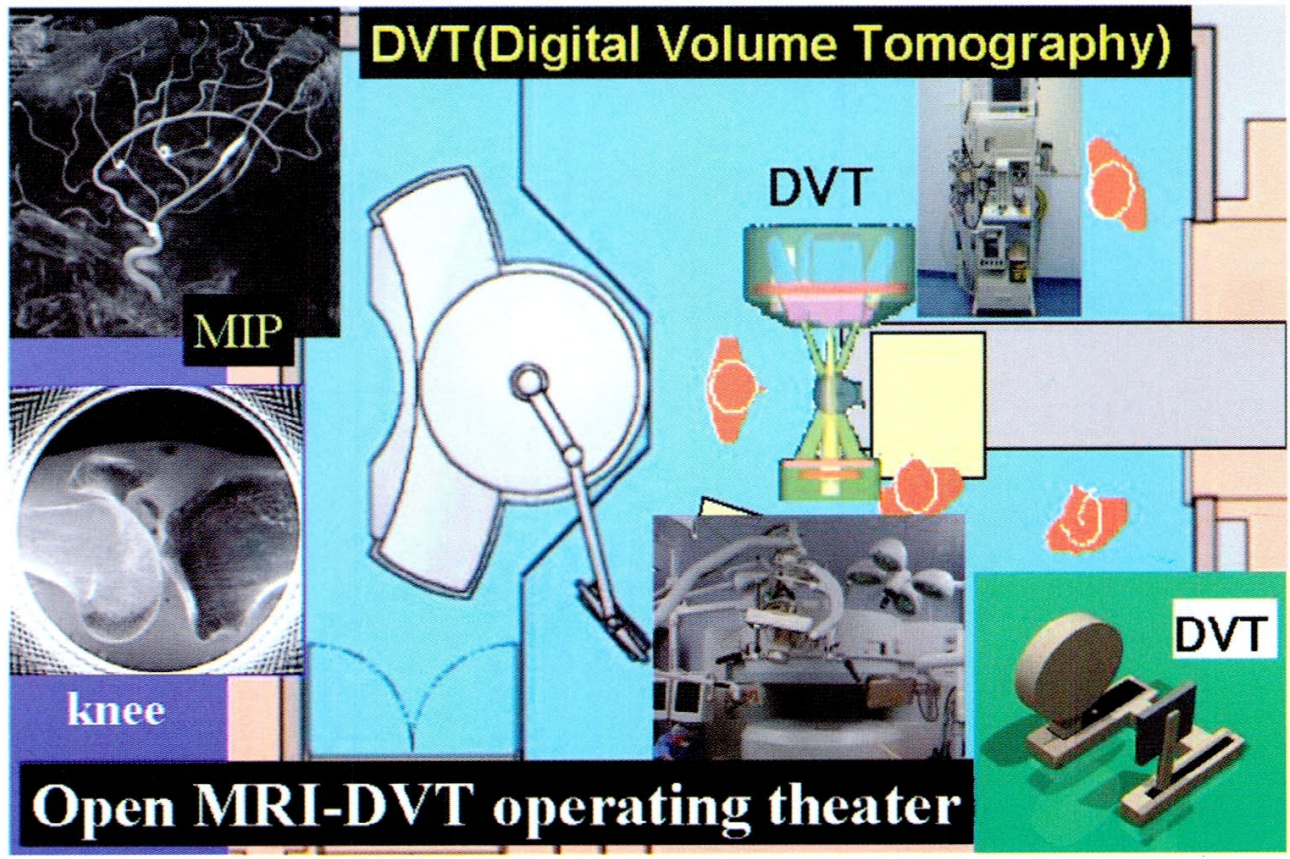

Fig. 3 Open MRI-DVT 手術室の概念図 
提供し, 快適とまではいかなくとも, 医療スタッフ・患者 の違和感を緩和する必要がある. 基本的なプロセスは, (1)

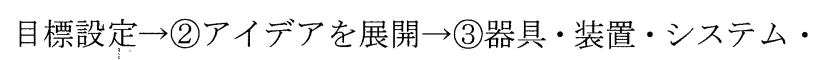
支援情報機能をデザイン(基本特許) $\rightarrow$ (4)製作とその結果 についての調査および評価 $\rightarrow$ (5)feed back $\rightarrow$ (3)に戻り評価 が確定した段階で一臨床利用・論文化・特許化・企業化・ 標準化を遂行する。一番重要なのは, 目標設定の条件であ る. したがって, 使用者の視点で調査し, 問題点の定義(二 一ズ)と技術的条件(シーズ)をピックアップし, 両者のすり 合わせをすることが肝要である.また, 運用にあたっては, 医療現場での不自然な形状・システムの発掘することが絶 対に重要で, 不自然な形状・動作・システムのような潜在 的問題点を, 使用者の技術でカバーする前に指摘すること につきる. 開発設計の原則は, 医療機器の開発だけでなく, それを使うシステム・環境全体を考えた設計である. 新し いテクノロジーの性能を優先するのではなくて, それを使 う環境やシステムが伴って初めてその性能を発揮すると いう原則に基づいた設計思想が重要である.さらに, 手術 工程解析に基づく時々刻々と変化する術野での手術操作 と使用器具のリスクアセスメントを行ない, その残留リス クの評価と低減についても留意する必要がある. バリアフ リーではなくユニバーサルフリーとしての設計思想で, 在 宅医療・遠隔医療での使用を見据えた開発・設計も重要で ある.すなわち患者自身が機器を扱う状態下では誰もが使 えて, 誤って操作をしても安全性が確保できる工夫が必須 である。

\section{5. インテリジェント手術室}

インテリジェント手術室では, 術中画像特に MRI の形 態を中心とした画像だけでは無く, 種々のイメージングを 活用した高度な利用形態が必須である ${ }^{6)}$. 手術操作による 臓器の変形や移動に追随するには術前画像だけでは不足 で, 術中に診断装置を稼動させて術中画像を取得し, ナビ ゲーション情報を更新する必要がある. 実際, mobile CT や診断用 CT を手術室に導入し, 術中に CT 画像でモニタ リングすることは従来から行なわれている. 手術の進展に 応じて, 得られた術中のボリュームデータから腫瘍の三次 元画像や三次元 CT 血管像を描出し, 手術の進渉状況を評 価している. 現在では, 毎秒 32 枚の CT 像を撮影しなが らほぼリアルタイムで表示できるマルチスライス CT fluoroscopy が市販されており, 脳手術・生検・Interventional Radiology(IVR)などに応用されている. Interventional MRI に代表される手術室での MRI による画像誘導手術が標準 的な手技として世界で運用されている.リアルタイム性を 追記有する場合には, 秒間 2 枚程度の二次元のフルオロ画
像が多用されている. CT と違って医療スタッフの X 線被 曝がなく, 16-32 列のマルチスライス CT と同様にボリュ 一ム撮像も容易である.開頭などの手術操作を伴う場合に は，MRI では放射線科の常識である診断画像と異なり， 診断では使用頻度が少ないと思われるボリュームデータ が主として活用される. ボリューム撮像の利点としては, 短時間(約 5 分)であることと任意断面(axial, sagittal, coronal, recommended plane)が同時に表示可能な画像データである ことが挙げられる. 術者の要求に応じた axial, sagittal, coronal plane のたびごとに撮像する必要はない.

医療スタッフの要望に応じて, 必要な鳥瞰図や手術経路 に沿った三次元断面像などが双方向的にリアルタイムに 表示することができる．超音波像は CT や MRI に比べて 画質と位置精度は劣るが, 即時性と取扱いの簡便さにおい て優れている. 超音波画像の三次元利用は, 子宮内の胎児 の描画や心臓の弁機能の解析など CT や MRI が適用され る領域と違う分野で活躍している. 画質の向上においても, 超音波用造影剤の応用も進められている. 血管径の計測や 血流の計測など診断のリアルタイム性が治療に直結する 分野での活躍が目立っている.この様に術中画像は, 術者 の要求度に応じて, 選択されるべきものなのである. 超小 型ガンマカメラが実用化し, 術中に使用されているガンマ カメラの小型化と伴に, RI(radio isotope)を利用して病変部 を標識し, 術中に標識組織を可視化しながら病変部を的確 に且容易に摘出する術中臨床応用が進められ, センチネル リンパ節を同定する RI-guided surgery が脚光を浴びている. 術中に大腸がんや直腸がんをより精度良く, 正確に摘出す る目的で免疫核医学を応用した免疫 RI ガイド手術 (radioimmunoguided surgery)や乳がんのセンチネルリンパ 節生検への臨床応用が始まり, 更に脳腫瘍への応用も試み られている ${ }^{7)}$. SPECT (single photon emission tomography) は, PET (positron emission tomography) に比べて空間分解 能は劣るが, 放射性医薬品を注射後 24 時間後に術中で検 出しながらすることも可能で, 逆に PET の被曝問題を解 決することができる. 悪性腫瘍そのものをガンマカメラで 検出する免疫 RI ガイド手術の進展や病変の組織部位など や手術スケジュールなどにより, 適切な放射性医薬品の選 択が成されれば，RI誘導手術が，CT/MRI 誘導手術と並ん で使われる日も近い. また, 術中イメージング装置として, 現在開発が進められている DVT (digital volume tomography）は，第 3 のボリューム CT ともいうべきもの である. 透視装置のように上部開口部は広く, 腹部領域を もカバーできる側部の開口部は, 全身の CT とも言うべき スペックを持っている. MR 対応として開発されており, オープン MRI 室で, 近未来の MRI-DVT 誘導手術が行な 
われる日も近い ${ }^{8)}$.

\section{6. おわりに}

本邦では, 従来システムの欠陷を人がカバーすることで システムに起因するトラブルを防いできた. 教育水準の均 等化による良質な労働力の確保が，これらを可能にしてき たが，近年，これらの条件は徐々に悪化してきている．ト ラブルは，必ずしも，従事する人間が悪いのではなく，シ ステムや環境の欠陥によることが多い. 特に不要なステッ プの削減が必須である。信頼度 95\%のステップが 25 あれ ば，それだけで全体の信頼度は $28 \%$ にがることになる。 目的を安全かつ確実に達成するためにも, 不要なプロセス の削減およびシステムの簡素化が必須である.さらに, 新 しいシステムを導入するならば, 環境やルールもそれに合 わせて変えなければいけないことも原則である，例えば， ロボットで脳外科手術をするという目標を達成するため には, 人とハードウェアとソフトウェアの選定から, 研究 開発・臨床応用チームの構成, 開発スケジュールのロード マップ管理までの沢山の項目をある程度のレベルまでに 仕上げることが不可欠である.そのジェネラルマネージメ ント能力には, 次の三つが必須である。技術的能力 (technical skill), 人間的能力 (human skill), 総合的把握力 (conceptual skill) である ${ }^{9)}$. また, マスタースレーブマニ ピュレータの製作，手術用器具類（把持装置，切開装置， スレーブマニピュレータをコントロールするヒューマン インターフェースなど多数), メンテナンス, 実験・臨床 応用しながらのチューニング, 手術サポートなどオペレー ションの内容は技術開発・臨床応用により多岐にわたる. 手術マネージメントもまた重要である.手術スタッフの人 選, 手術チームの編成, チューニング作業での医学系・工 学系スタッフとの協力法, 手術スタッフのトレーニング法, 医療情報収集と分析, 脳外科ロボット手術戦略立案・運用 などすべてにオペレーションマネージメントが必要であ る. 手術支援とは, 単なる医療画像を術者にわかり易く提 示することで事足れりというわけには行かないのである. 医療画像は, 場面場面に必要な医療情報を術者や手術ス夕 ッフに直感的に提示する技術そのものである. 技術の進展 と伴に, 医療画像の表示は単純なものから複雑なのもまで 多岐にわたる. しかし, ここで要求される表示とは, 無駄 を排した研ぎ澄まされた要求に応じた, スピードを持った 単純かつ明確な意思を伝える事が可能なものである. その 目的に応じて, ワイヤーフレームからレンダリング, 二次 元から三次元表示など必要な要求をスピードとシンプル および直感的な基準を基に個々の場面で決定されるべき ものであり, 全体を常に見据えた最適な表示手段を提供す ることに尽きる。

\section{文献}

1）伊関 洋，南部恭二郎，杉浦 円，苗村 潔，高倉公朋，藤 江正克. 脳神経外科手術におけるロボット技術への期待と課題. 特集一医療支援用ロボット技術。ロボット 2001; 141: 12-18.

2) Hongo K, Kobayashi S, Kakizawa Y, Koyama J, Goto T, Okudera H, Kan K, Fujie M, Iseki H, Takakura K. NeuRobot: Telecntrolled Micromanipulator System For Minimally Invasive Microneurosurgery-Preliminary Results Neurosurgery 2000; 51: 985-988.

3）伊関 洋，奥寺 僘，谷崎義生，村垣善浩，小林茂昭，吉本 高志, 堀 智勝, 高倉公朋:外科医の新しい目・手・脳. 21 世 紀の定位脳手術．機能的脳神経外科 2001; 40: 1-7.

4) Iseki H, Muragaki $Y$, Taira $T$, Kawamata $T$, Maruyama $T$, Naemura K, Nambu K, Sugiura M, Hirai N, Hori T., Takakura K. New Possibilities for Stereotaxis Information-Guided Stereotaxis. Stereotactic and Functional Neurosurgery 2001; 76: 159-167.

5) 伊関 洋, 氏家弘. E-ナイチンゲール(医療のトレーサビリ ティー)一看護過程履歴管理の自動記録・分析による看護業務 の改善/Topics. 医学のあゆみ 2003;204(8):568-569.

6) 伊関 洋, 村垣善浩, 南部恭二郎, 杉浦 円, 谷口拡樹, 丸 山隆志, 中村亮一, 堀 智勝, 高倉公朋. 脳のための最先端手 術室 特集 脳と医科機械. 医器学 2003;73(7):358-363.

7) 土持 眞. RI ガイド手術のための小型高分解能ガンマカメラ. 日本医学放射線技術学会雑誌 2000; 57(7):751-758

8) Nambu $K$, Nomura $S$, Ohyu S. Digital volume tomography : a new three-dimensional imaging apparatus designed for intraoperative examination. Lemke HU, et al Eds. In: Computer Assisted Radiology and Surgery ; CARS2003, London. Elsevier; Amsterdam, 2003; 1295 .

9) 宮田秀明.アメリカズカップのテクノロジー、Nippon Challenge America’s Cup. 東京大学出版会 ; 東京. 2000 . 